\section{GAMBAR DAN RUPA ALLAH}

Pdt. Jermia Djadi, M.Div.

\section{Pendahuluan}

Berdasarkan kitab Kejadian 1:26 Allah menciptakan manusia "atas peta dan teladan Allah" (Bode) atau "menurut gambar dan rupa Allah" Lembaga Alkitab Indonesia (LAI). Dalam uraian selanjutnya penulis akan memakai ungkapan yang digunakan oleh LAI, yaitu "gambar dan rupa Allah." Menurut catatan Alkitab, dari segala sesuatu yang diciptakan Allah, hanya manusialah yang diciptakan menurut "gambar dan rupa Allah" dan inilah yang membedakan manusia dengan semua ciptaan yang lain.

Doktrin tentang gambar dan rupa Allah ini akan diuraikan dengan sistematika sebagai berikut: Pendahuluan, beberapa pandangan tentang gambar dan rupa Allah dalam diri manusia, data Alkitab tentang gambar dan rupa Allah dalam diri manusia, dan kesimpulan.

\section{Beberapa Pandangan Tentang Gambar dan Rupa Allah Dalam Diri Manusia}

\section{Pandangan Bapak-Bapak Gereja}

Pertama, Irenius dan Tertullian membedakan antara "gambar" dan "rupa" Allah. Menurut mereka bahwa "gambar" terkait dalam tubuh manusia, sedangkan "rupa" berkaitan dengan sifat spiritual manusia.

Kedua, Clement dari Alexandria dan Origen menolak setiap pengertian tentang analogi dari tubuh dan menganggap bahwa kata "gambar" menunjukkan ciri-ciri khas manusia sebagai manusia dan kata "rupa" menunjukkan kualitas yang tidak esensial bagi manusia, tetapi dapat dibudidayakan atau terhilang. Pandangan ini juga dianut oleh Athanasius, Hilary, Ambrose, Agustinus dan John dari Damaskus.

Ketiga, Menurut Pelagius dan para pengikutnya, gambar hanya berarti bahwa manusia diberkati dengan pikiran, sehingga ia dapat mengenal Allah. Dengan kehendak bebasnya, ia dapat memilih dan melakukan kebaikan, dan dengan kekuatan yang perlu untuk memerintah ciptaan yang lebih rendah.

\section{Pandangan Para Reformator}

Para reformator menolak pembedaan antara gambar dan rupa Allah dan mereka menganggap kebenaran asali sebagai sesuatu yang sudah tercakup dalamnya dan menjadi milik dari sifat manusia yang paling mendasar dalam keadaannya semula. Di samping itu, ada juga perbedaan pendapat antara Luther dan Calvin.

Pertama, Luther tidak mencari gambar dan rupa Allah dalam penampakan fisik manusia, seperti misalnya kekuatan rasional atau moral, tetapi semuanya di dalam kebenaran asali, dan dengan demikian, ia menganggap semua itu hilang dalam dosa.

Kedua, Calvin menyatakan pendapatnya bahwa gambar dan rupa Allah mencakup segala sesuatu di mana sifat dasar manusia mengatasi segala sifat binatang (Louis Berkhof, 1994: 43$45)$.

\section{Pandangan Gereja-Gereja.}

Di bawah ini akan dikemukakan pandangan Gereja Reformed, Gereja Lutheran, dan Gereja Roma Katolik tentang gambar dan rupa Allah dalam diri manusia. 


\section{Pandangan Gereja Reformed}

Gereja-gereja Reformed yang mengikuti jejak Calvin memiliki konsep yang lebih lengkap dan menyeluruh tentang gambar dan rupa Allah jika dibandingkan dengan Gereja-gereja Lutheran atau Gereja Roma Katolik. Akan tetapi mereka juga tidak semuanya setuju pada isinya secara pasti, misalnya:

Pertama, Dabney mengatakan bahwa gambar dan rupa Allah tidak termasuk dalam segala sesuatu yang mutlak esensial pada sifat manusia, sebab kehilangan gambar dan rupa Allah itu akan membawa kehancuran sifat manusia; akan tetapi semata-mata dalam beberapa kebetulan.

Kedua, McPherson menegaskan bahwa gambar dan rupa Allah itu adalah milik sifat esensial manusia. Jika gambar dan rupa Allah itu hilang, maka manusia akan berhenti menjadi manusia. Dalam menjawab pertanyaan, apakah gambar dan rupa Allah merupakan milik dari esensi manusia yang paling mendasar? Teologi Reformed tidak ragu-ragu mengemukakan bahwa gambar dan rupa Allah ini membentuk esensi manusia. Akan tetapi teologi Reformed membedakan antara elemen-elemen dalam gambar dan rupa Allah yang tidak mungkin hilang dari manusia tanpa berhenti menjadi manusia, termasuk dalam kualitas esensial dan kekuatan dari jiwa manusia, dan elemen-elemen yang dapat hilang dari manusia, tetapi tetaplah menjadi manusia, yaitu kualitas etis yang baik dari jiwa dan kekuatannya. Gambar dan rupa Allah dalam arti sempit sama dengan kebenaran asali. Gambar dan rupa Allah ini adalah kesempurnaan yang mungkin hilang karena dosa.

\section{Pandangan Gereja Lutheran}

Konsep Gereja Lutheran yang masih dipegang sampai sekarang tentang gambar dan rupa Allah berbeda secara material dengan konsep teologi Reformed.
Teolog-teolog Lutheran sebagian besar memiliki konsep tentang gambar dan rupa Allah dengan membatasinya hanya sebagai kualitas spiritual yang dikaruniakan kepada manusia, yaitu apa yang disebut sebagai kebenaran asali. Manusia kehilangan gambar dan rupa Allah seluruhnya karena dosa dan apa yang membedakan manusia dengan binatangbinatang secara teologis dan religius tidaklah penting. Perbedaan besar antara keduanya terletak pada gambar dan rupa Allah dan sekarang manusia telah kehilangan gambar dan rupa Allah itu. Barth lebih dekat dengan pandangan Gereja Lutheran, dia berkata bahwa gambar dan rupa Allah bukan saja dirusakkan, tetapi menjadi hilang sama sekali karena dosa.

\section{Pandangan Gereja Roma Katolik}

Orang-orang Roma Katolik sendiri tidak semuanya memiliki konsep yang sama tentang gambar dan rupa Allah. Walaupun demikian, di sini akan dikemukakan hanya pendapat yang paling banyak diterima di antara mereka. Mereka berpendapat bahwa ketika Allah menciptakan, Ia memberi manusia sejumlah karunia natural, seperti: spiritualitas, jiwa dan kekekalan tubuh. Kerohanian, kebebasan berkehendak, dan kekekalan adalah pemberian natural dan semua ini membentuk gambar dan rupa alamiah manusia. Lebih jauh lagi Allah menyesuaikan kekuatan natural manusia satu dengan yang lain, menempatkan yang lebih rendah di bawah yang lebih tinggi. Keselarasan yang diperoleh kemudian disebut sebagai kebenaran asali. Akan tetapi tetaplah tinggal dalam diri manusia suatu kecenderungan natural dari keinginan yang lebih rendah serta nafsu-nafsu untuk melawan dan memberontak pada otoritas kekuatan yang lebih tinggi dari pemikiran dan hati nurani. Kecenderungan itu sendiri bukanlah dosa, tetapi menjadi dosa bila 
dilaksanakan dalam tindakan yang didorong oleh kehendak. Dalam upaya untuk memungkinkan manusia untuk senantiasa menjaga sifat yang lebih rendah yang ada dalam diri manusia, maka Allah menambahkan kesempurnaan supranatural kepada kesempurnaan natural. Penambahan ini mencakup kesempurnaan supranatural dari kebenaran asali, yang ditambahkan sebagai suatu pemberian asing bagi konstitusi asli manusia, baik secara langsung pada waktu penciptaan maupun pada waktu selanjutnya sebagai anugerah karena manusia memakai kekuatan naturalnya dengan tepat. Karunia-karunia supranatural ini termasuk juga kesempurnaan supranatural dari kebenaran asali, kemudian hilang karena dosa, tetapi ini tidaklah merusakan seluruh sifat esensial manusia (Louis Berkhof, 1994: 52-55).

\section{Data Alkitab Tentang Gambar dan Rupa Allah Dalam Diri Manusia}

Alkitab menyatakan bahwa Allah menciptakan manusia menurut gambar dan rupa Allah (Kejadian 1:26-27; 5:1-3; 9:6; I Korintus 11:7; Yakobus 3:9). Tampaknya tidak ada perbedaan di antara kata-kata Ibrani untuk tselem, "gambar" dan demut, "rupa", sehingga tidak perlu mencari-cari perbedaan itu. Kata "gambar" dan "rupa" dipakai secara bersinonim dan dipakai saling bergantian. Dengan demikian, kata-kata itu tidak menunjuk dua hal yang berbeda. Dalam Kejadian 1:26, kata "gambar" dan "rupa" dipakai, tetapi dalam ayat 27 hanya kata "gambar" dipakai. Dalam Kejadian 5:1 hanya kata "rupa" dipakai, tetapi dalam ayat 3 kata "rupa" dan "gambar" muncul lagi. Kejadian 9:6 hanya memakai kata "gambar" untuk menunjukkan keseluruhan. Jika kita melihat Perjanjian Baru, kita dapati kata "gambar" dan "kemuliaan" dipakai dalam I Korintus 11:7. "Gambar" dipakai dalam Kolose 3:10, dan "rupa" ditulis dalam Yakobus 3:9. Jadi jelas bahwa kedua kata itu dipakai secara bergantian dalam Alkitab. Kenyataan ini cukup untuk mendukung keseluruhan ide ini, yaitu bahwa istilah "gambar" dan "rupa" menunjuk hal yang sama.

Namun perlu dibahas, dalam hal apakah kesamaan antara manusia dengan Allah, seperti yang terdapat dalam ungkapan, "Baiklah Kita menjadikan manusia menurut gambar dan rupa Kita, ..." (Kejadian 1:26).

Pertama, Kesamaan itu adalah kesamaan rohani. Hodge, sebagaimana dikutip oleh Henry C. Thiessen yang mengatakan, "Allah adalah Roh, jiwa manusia adalah roh juga. Sifat-sifat hakiki dari roh ialah akal budi, hati nurani, dan kehendak. Roh adalah unsur yang mampu bernalar, bersifat moral, dan oleh karena itu juga berkendak bebas. Ketika menciptakan manusia menurut gambarNya, Allah menganugerahkan kepadanya sifat-sifat yang dimiliki-Nya sebagai roh. Dengan demikian, manusia berbeda dari semua makhluk lain yang mendiami bumi ini, serta berkedudukan jauh lebih tinggi daripada mereka. Manusia termasuk golongan yang sama dengan Allah sendiri sehingga mampu berkomunikasi dengan Penciptanya. Kesamaan sifat antara Allah dan manusia... juga merupakan keadaan yang diperlukan untuk mengenal Allah dan karena itu merupakan dasar dari kesalehan kita. Bila kita tidak diciptakan menurut gambar Allah, kita tidak dapat mengenal Dia. Kita akan sama dengan binatang yang akhirnya binasa" (Henry C. Thiessen, 1992: 237). Pernyataan Hodge di atas didukung oleh Alkitab. Dalam pengudusan, manusia “...terus-menerus diperbaharui untuk memperoleh pengetahuan yang benar menurut gambar Khaliknya" (Kolose 3:10). Sudah tentu pembaruan itu dimulai pada saat terjadi kelahiran kembali dan dilanjutkan dalam pengudusan. Manusia 
diberi kemampuan intelektual yang tinggi tersirat dalam perintah untuk mengusahakan Taman Eden (Kejadian 2:15), juga perintah untuk menguasai bumi serta segala isinya (Kejadian 1:28), dan dalam pernyataan bahwa manusia memberi nama kepada segala binatang di bumi (Kejadian 2:19-20). Kesamaan dengan Allah ini tidak dapat dihapus, maka kehidupan manusia yang belum dilahirkan kembali juga berharga (Kejadian 9:6; I Korintus 11:7; Yakobus 3:9). Gambaran tentang keadaan mula-mula manusia ini sangat berbeda dengan pandangan evolusi. Menurut teori evolusi, manusia yang pertama hanya sedikit di atas binatang liar - yang tidak hanya bodoh, tetapi sama sekali tanpa kemampuan mental apa pun.

Kedua, Kesamaan itu adalah kesamaan moral. Kesamaan moral artinya manusia dilengkapi dengan kebenaran dan kekudusan. Hal itu sangat jelas dalam Alkitab, seperti yang diungkapkan dalam Efesus 4:24, "Dan mengenakan manusia baru, yang telah diciptakan menurut kehendak Allah di dalam kebenaran dan kekudusan yang. sesungguhnya." Dapat disimpulkan bahwa pada mulanya manusia memiliki, baik kebenaran maupun kekudusan. Konteks Kejadian 1 dan 2 membuktikan hal itu, yaitu ketika manusia diciptakan, sebelum kejatuhannya ke dalam dosa. Hanya dengan dasar kebenaran dan kekudusan inilah manusia dapat bersekutu dengan Allah. Kenyataan ini juga dapat disimpulkan dari Kejadian 1:31 yang mengatakan, "Allah melihat segala yang dijadikan-Nya itu, sesungguhnya amat baik." Kata "segala" mencakup juga manusia yang diciptakan dengan keadaan moral yang sempurna.

Apakah yang dimaksud dengan kebenaran dan kekudusan mula-mula? Kebenaran dan kekudusan mula-mula bukanlah hakikat manusia, karena dengan demikian watak manusia pasti sudah tidak ada lagi ketika ia berbuat dosa. Kebenaran dan kekudusan mulamula juga bukan pemberian dari luar, yaitu sesuatu yang ditambahkan kepada manusia setelah ia diciptakan, karena dikatakan bahwa manusia memiliki gambar dan rupa Allah itu ketika ia diciptakan dan bukan karena dikaruniakan kepadanya setelah diciptakan.

Thiessen mengutip penjelasan Shedd sebagai berikut, "Kekudusan bukanlah sekadar keadaan tidak berdosa. Tidaklah memadai untuk mengatakan bahwa manusia diciptakan dalam keadaan tidak berdosa. Hal ini dapat dikatakan apabila manusia sama sekali tidak memiliki watak yang moral, entah itu benar atau salah. Manusia diciptakan bukan saja sebagai makhluk yang tidak berdosa secara negatif, tetapi juga sebagai makhluk kudus secara positif. Keadaan manusia yang diperbarui adalah pemulihan keadaannya yang semula; dan kebenaran manusia yang telah diperbarui disebut dalam Alkitab sebagai kata theon (Efesus 4:21) dan sebagai kekudusan yang sesungguhnya (Efesus 4:24). Ini merupakan watak yang positif dan bukan sekadar keadaan tidak berdosa" (Henry C. Thiessen, 1992: 239). Kekudusan mulamula ini dapat diartikan sebagai kecenderungan kasih sayang dan kehendak manusia ke arah pengetahuan rohani tentang Allah dan hal-hal yang berhubungan dengan Allah pada umumnya, sekalipun disertai kesanggupan untuk salah pilih.

Ketiga, Kesamaan itu adalah kesamaan sosial. Sifat sosial Allah didasarkan pada kasih sayang-Nya. Yang menjadi sasaran kasih sayang-Nya adalah pribadi-pribadi lain di dalam ketritunggalan-Nya. Karena Allah memiliki sifat sosial, maka Ia menganugerahkan kepada manusia sifat sosial. Akibatnya, manusia senantiasa mencari sahabat untuk bersekutu dengannya. Pertama- 
tama manusia menemukan persahabatan ini dengan Allah sendiri. Allah menciptakan manusia untuk diri-Nya sendiri dan manusia menemukan kepuasan tertinggi dalam persekutuan dengan Tuhannya. Di samping itu, Allah juga menganugerahkan persahabatan manusiawi. Ia menciptakan perempuan, karena sebagaimana dikatakan-Nya sendiri, "Tidak baik kalau manusia itu seorang diri saja. Aku akan menjadikan penolong baginya yang sepadan dengan dia" (Kejadian $2: 18$ ). Agar persekutuan ini menjadi sangat mesra, Ia menciptakan perempuan dari tulang rusuk laki-laki. Adam mengakui bahwa Hawa adalah tulang dari tulangnya dan daging dari dagingnya, maka dinamakannya perempuan. Oleh sebab hubungan yang begitu intim di antara keduanya, "Seorang laki-laki akan meninggalkan ayahnya dan ibunya dan bersatu dengan istrinya, sehingga keduanya menjadi satu daging" (Kejadian 2:24). Jelaslah bahwa manusia diciptakan dengan sifat sosial, sebagaimana Allah mempunyai sifat sosial. Kasih dan perhatian sosial manusia bersunber langsung dari unsur ini dalam watak manusia.

\section{Kesimpulan}

Menurut Alkitab bahwa esensi manusia tercakup dalam hal bahwa manusia adalah gambar dan rupa Allah, yang berarti manusia memiliki kesamaan dengan Allah, yaitu kesamaan rohani, kesamaan moral, dan kesamaan sosial. Dengan demikian, manusia berbeda dengan semua makhluk ciptaan yang lain dan menjadi yang tertinggi di mana manusia sebagai mahkota ciptaan Allah atas seluruh ciptaan. Alkitab mengakui bahwa manusia diciptakan menurut gambar dan rupa Allah atau segambar dan serupa dengan Allah (Kejadian 1:2627; 9:6; Yakobus 3:90), dan Alkitab juga berkata bahwa manusia adalah pembawa gambar Allah (I Korintus $11: 7 ; 15: 49$ ). Sebagaimana telah dijelaskan di atas bahwa kedua kata, "gambar" dan "rupa" menunjuk pada pengertian yang sama. Pengertian yang diungkapkan oleh kedua kata itu menunjukkan bahwa manusia sungguh-sungguh memiliki kesamaan dengan Allah.

Doktrin tentang gambar dan rupa Allah dalam diri manusia sangat penting dalam teologi, sebab gambar dan rupa Allah ini adalah suatu kualitas yang menjadikan manusia istimewa dalam hubungannya dengan Allah. Kenyataan bahwa manusia adalah gambar dan rupa Allah menjadikan manusia berbeda dengan binatang dan dengan semua makhluk yang lain. Sejauh kita dapat belajar dari Alkitab bahwa malaikat pun tidak mendapat kemuliaan ini, walaupun kadang-kadang malaikat dikatakan seolah-olah memiliki kemuliaan sedemikian. Alkitab menegaskan pula bahwa manusia satu-satunya makhluk ciptaan yang segambar dan serupa dengan Allah yang memiliki kualitas untuk menguasai segala ciptaan-Nya yang lain (Kejadian 1:28), untuk menghakimi dunia, bahkan untuk menghakimi malaikat-malaikat (I Korintus 6:2-3).

Dengan mengetahui bahwa manusia adalah ciptaan Allah yang termulia, karena diciptakan menurut gambar dan rupa Allah, maka manusia wajib menghargai dirinya dan sesamanya sebagai ciptaan yang mulia dan mau menyatakan gambar dan rupa Allah dalam kehidupan sehari-hari, melalui kerohanian, moral yang baik, dan kehidupan sosial dengan mengasib: sesama manusia seperti diri sendi Amin. 


\section{KEPUSTAKAAN}

Becher, Teol. Dieter. 1991. Pedoman Dogmatika. Jakarta: BPK Gunung Mulia.

Berkhof, Louis. 1994. Teologi Sistematika Volume 2: Doktrin Manusia. Jakarta: Lembaga Reformed Injili Indonesia. Hadiwijono, Harun. 1988. Iman Kristen. Jakarta: BPK Gunung Mulia, Cetakan Keenam.

Ryrie, Charles C. 1991. Teologia Dasar Volume 1. Yogyakarta: Yayasan Andi, Cetakan Pertama.

Thiessen, Henry C. 1992. Teologi Sistematika. Malang: Penerbit Gandum Mas, Cetakan Pertama.

Van Nifrik, G. C. 1990. Dogmatika Masa Kini. Jakarta: BPK Gunung Mulia.
Pdt. Jermia Djadi, M.Div. Dosen dan Puket II STT Jaffray

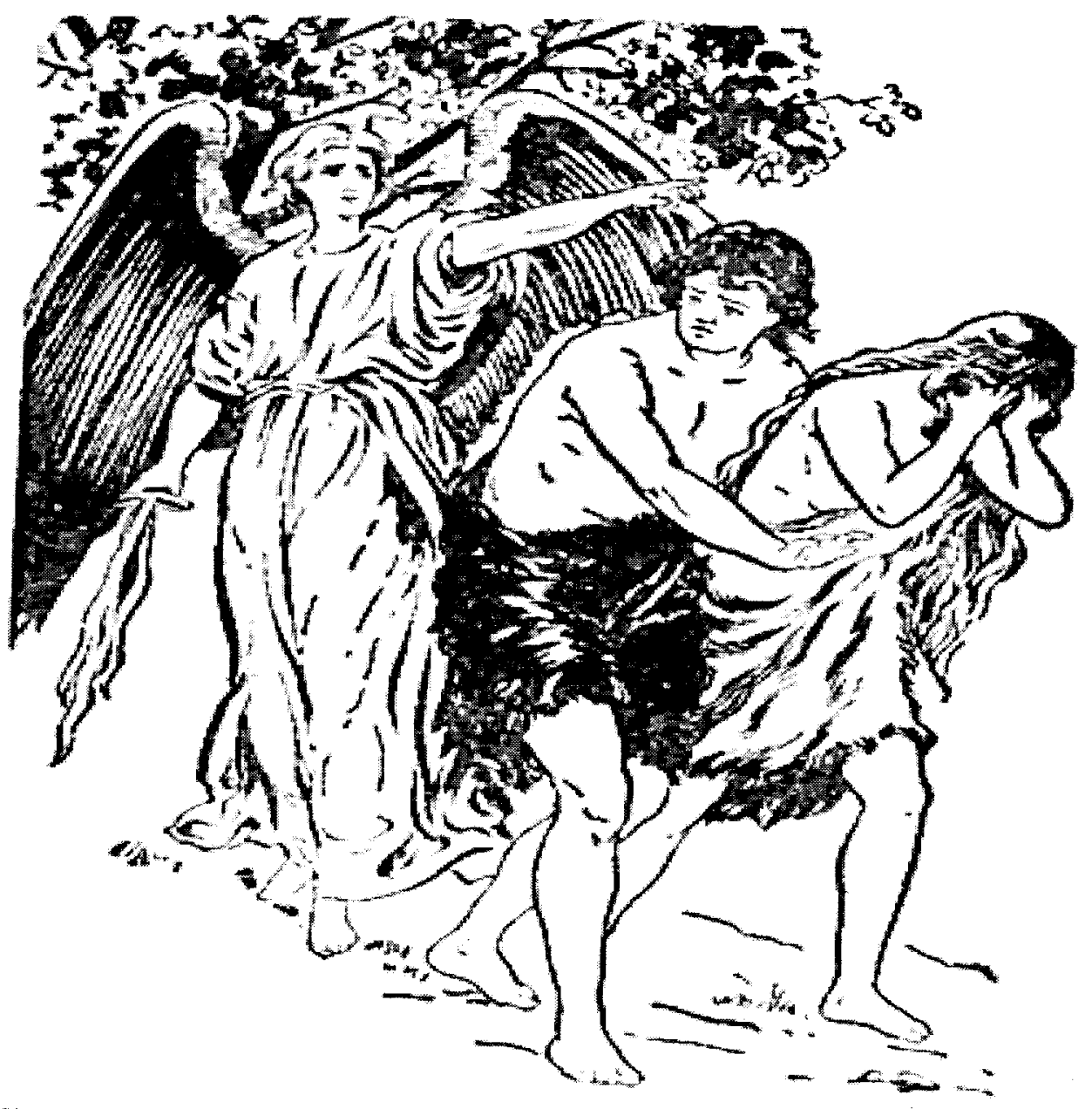

